Türk Turizm Araştırmaları Dergisi
2020, 4(2): 797-810.
DOI: $10.26677 /$ TR1010.2020.366

\title{
Elektronik-Ağızdan Ağıza İletişim (E-AAİ) Aracılığıyla Otel İmajının İrdelenmesi: Antalya Örneği
}

Dr. Öğr. Üyesi Veli Erdinç ÖREN, Uşak Üniversitesi, Banaz MYO, Uşak, e-posta: erdinc.oren@usak.edu.tr

ORCID: https://orcid.org/0000-0002-7614-644X

Dr. Öğr. Üyesi Ozan ÇATIR, Uşak Üniversitesi, Ulubey MYO, Uşak, e-posta: ozan.catir@usak.edu.tr

ORCID: https://orcid.org/0000-0003-3168-7338

Öz

Tüketiciler, turizm ürününü satın alırken ve satın aldıktan sonra elektronik ortamlarda deneyimlerini paylaşmaktadırlar. Paylaşılan bu deneyimler daha sonra turizm ürününü satın alacak diğer tüketicilerin satın alma kararlarını olumlu veya olumsuz olarak etkilemektedir. Otel işletmelerinin tüketiciler gözündeki imajını bu ortamlardaki verilere göre analiz etmeleri ve itibarlarını bu şekilde yönetmeleri karlılıkları açısından büyük önem arz etmektedir. Tüketiciler tarafından oluşturulan bu içerikler büyük bir veri yığınına dönüşmüştür. Bu büyük veri yığının analizi ancak bilimsel metin madenciliği yöntemleriyle mümkün olabilmektedir. Çalışmanın amac1, otellere ilişkin yorumlar incelenerek, otellerin kurumsal imajlarının irdelenmesidir. Bu çalışmada metin madenciliği yönteminden faydalanılarak, bir seyahat sitesinde Antalya'da faaliyet gösteren otuz beş beş yıldızlı otel işletmesinden elde edilen 18061 çevrimiçi yorum analiz edilmiştir. Bulgular incelendiğinde Antalya beş yıldızlı otellerinin tüketicilerin değerlendirmelerine göre olumlu bir imaja sahip olduğu sonucuna ulaşılmıştır. Yapılan analizler sonucunda turistlerin en fazla otelin fiziki yapısı hakkında yorum yaptığı görülmektedir. Fiziki yapının ardından yemek, personel, oda ve hizmet konuları hakkında yorum yapılmıştır. Fiyat ise en az yorum yapılan bir boyut olduğu tespit edilmiştir.

Anahtar Kelimeler: Elektronik Ağızdan Ağıza İletişim, Otel İmajı, Metin Madenciliği, Otel İşletmeleri.

Makale Gönderme Tarihi: 17.12.2019

Makale Kabul Tarihi: 02.04.2020

Önerilen Atıf:

Ören, V. E. ve Çatır, O. (2020). Elektronik-Ağızdan Ağıza İletişim (E-AAİ) Aracılığıyla Otel İmajının İrdelenmesi: Antalya Örneği, Türk Turizm Araştırmaları Dergisi, 4(2): 797-810.

(c) 2020 Türk Turizm Araştırmaları Dergisi. 


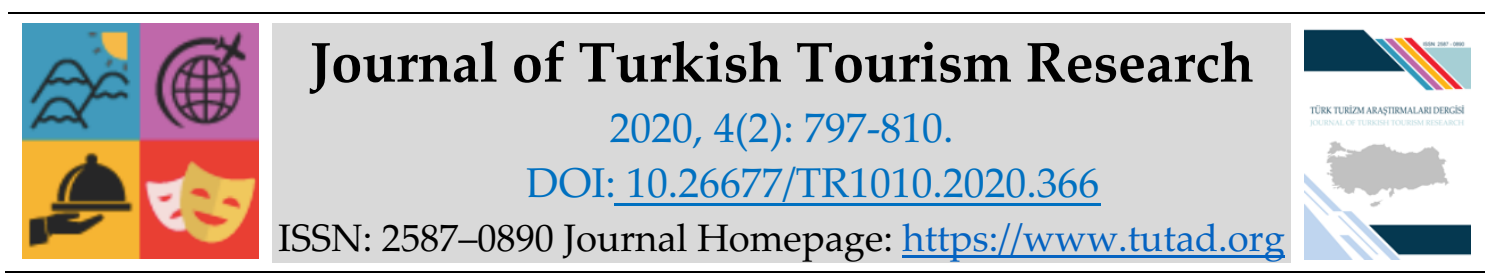

RESEARCH PAPER

\title{
Investigation of the Image of The Hotel Through Electronic-Word of Mouth Communication (EWOM): Antalya Case
}

\author{
Assistant Prof. Dr. Veli Erdinç ÖREN, Uşak University, Banaz Vocational School, Uşak, e-mail: \\ erdinc.oren@usak.edu.tr \\ ORCID: https://orcid.org/0000-0002-7614-644X
}

Assistant Prof. Dr. Ozan ÇATIR, Uşak University, Ulubey Vocational School, Uşak, e-mail: ozan.catir@usak.edu.tr

ORCID: https://orcid.org/0000-0003-3168-7338

\begin{abstract}
Consumers share their experiences electronically while purchasing or after the purchase of tourism products. These shared experiences affect the purchase decisions of other consumers who will buy similar tourism products positively or negatively. It is important for hotel businesses to analyze their image in the eyes of consumers according to the data in these environments and to manage their reputation in this way. The consumer-generated content has become a big data stack. The analysis of this big data stack is only possible with scientific text mining methods. The study aims to examine the institutional images of the hotels by reviewing the comments about the hotels. In this study, 18061 online comments obtained from thirty-five five-star hotels operating in Antalya on a travel site were analyzed using the text mining method. When the findings are examined, it is concluded that five-star hotels in Antalya have a positive image according to consumers' evaluations. As a result of the analyzes, it is seen that the tourists mostly comment on the physical structure of the hotel. Then, comments were made on food, staff, room and service issues. The price was found to be the least commented size.
\end{abstract}

Keywords: Electronic Word of Mouth Communication, Hotel Image, Text Mining, Hotel Businesses.

Received: 17.12 .2019

Accepted: 02.04.2020

Suggested Citation:

Ören, V. E. and Çatır, O. (2020). Investigation of the Image of The Hotel Through Electronic-Word of Mouth Communication (EWOM): Antalya Case, Journal of Turkish Tourism Research, 4(2): 797810.

(C) 2020 Türk Turizm Araştırmaları Dergisi. 


\section{Gíriş}

Hızla artan rekabet piyasasında birinci önceliği kar elde etme olan işletmeler, bu arzusunu gerçekleştirebilmek için önce müşteri memnuniyetini sağlamaları gerektiğini anlamıştır. Günümüz koşullarında işletmeler müşteri odaklı olmalıdır. İşletmenin başarısında müşteri ihtiyaçlarının belirlenmesi ve müşteri memnuniyetinin sağlanması ve bunun gerçekleştirilmesi önemli rol oynamaktadır (Marangoz ve Akyıldız, 2007:194). Bu nedenle işletmeler müşteri memnuniyetini etkileyen unsurları dikkate almak durumundadır. Artık işletmeler müşterilerini memnun ederek müşterilerinin sürdürülebilirliğini sağlama, yeni müşteriler kazanma ve işletme imajlarını geliştirmek için önemli çalışmalar yapmaktadır. İmajın kesin bir tanımı olmamakla beraber imaj; "kişiye, kuruma veya ülkeye ait düşünce ve izlenimlerin beyinde algılanması sonucu oluştuğu kabul edilen, farklı kişiler tarafından farklı anlamlar yüklenerek kullanılan bir kavram" olarak karşımıza çıkmaktadır (Zengin ve Gürkan, 2009:132). Moore imajın, bir işletmenin faaliyetlerinden ve performanslarından genel olarak memnuniyet derecesinin zihinsel bir tahmini olduğunu belirtmiştir. Keller marka imajını, tüketicilerin markayla olan çok boyutlu ilişkilerinden doğan algı olarak kavramlaştırmıştır. İşletmelerin amacı, markanın olumlu imajında ortaya çıkan sonuç hakkında olumlu bir bağlantı kurmaktır. Tüketici bir marka için daha fazla arzu duyabilir, çünkü bu marka diğer rakip markaların imajından farklıdır (Lin vd., 2013:34). Marka imajı tüketicilerin genel deneyiminden çok daha önemlidir. Çünkü marka imajı tüketicinin bilişsel, duygusal ve davranışsal tepkilerinin bir sonucu olarak ortaya çıkmaktadır (Padgett ve Allen, 1997:54). İşletmelerin olumlu bir imaj oluşturması, pazarlama faaliyetlerinin daha başarılı bir şekilde yapılmasını sağlamaktadır. Ayrıca rekabet ve kriz durumlarında işletmenin daha iyi bir konuma gelmesine neden olmaktadır. İşletmelerin olumlu bir imaj oluşturmaları müşteriye güven verme, saygınlık ve tanınma gibi faktörlerin yönetilmesiyle mümkün olmaktadır (Şimşek, 1998:358). Mevcut ve harici bilgilere dayanarak karar veren tüketiciler, marka imajı ve bilgi içeriği arasındaki ilişkiye göre satına alma yapmaktadır. Bu aşamada marka imajı ile elde edilen bilgiler arasında bir çelişki olduğunda tüketiciler karar vermekte zorlanacaktır (Lin vd., 2013:34). İmaj, turizm işletmeleri için turistik bir ürün olarak değerlendirilir. Turizm işletmelerinin tercih edilmesinde, işletmelerin sahip oldukları imaj önemli bir yere sahiptir (Kozak, 2014:130). Emek yoğun özelliğe sahip otel işletmeleri benzer özellik gösteren rakip otel işletmelerine göre bir farklılık yaratmak zorundadır. Sunulan mal ve hizmetler kapsamında birbiriyle büyük benzerlik gösteren otel işletmeleri için imaj önemli bir kavram haline gelmiştir. Bu bağlamda otel imajı tüketicilerin beğenisini etkileme gücüne sahiptir (Zengin ve Gürkan, 2009:132).

Ağızdan ağıza iletişimde (AAI) temel fikir, ürünler, hizmetler, mağazalar, işletmeler, vb. hakkındaki bilgilerin bir tüketiciden diğerine yayılabilmesidir. En geniş anlamıyla, AAİ bir hedef nesne hakkında herhangi bir bilgiyi içermektedir (Brown vd., 2005:124-125). AAİ, "tüketicilere belli bir ürün, marka veya hizmet hakkında sahip oldukları bilgi ve tecrübelerini paylaşma olanağ1 sunan bir süreçtir" (Güzel, 2014:194). AAİ'in tüketicilerin bilgi aramalarında ve sonraki karar verme süreçlerinde satın alma davranışları ve işletme imajı üzerinde güçlü bir etkiye sahip olduğu ve diğer tüketicilerin ürün tercihlerini etkileyen en inandırıcı bilgiyi sağladığ düşünülmektedir (Brown ve Reingen, 1987; Herr, Kardes ve Kim, 1991; Silverman, 1997; Money, Gilly ve Graham, 1998; Henricks, 1998; Ateşoğlu ve Bayraktar, 2011; Kitapcı vd., 2012; Lin vd., 2013; Kutluk ve Avcıkurt, 2014; Aydın 2016).

Tarihsel olarak, internetin hızla hayatımıza girmesiyle elektronik iletişim bir olay haline gelmektedir (Buttle, 1998). Gelişmiş iletişim yetenekleriyle internetin hızlı gelişimi, AAI'in ölçeğini ve kapsamını da önemli ölçüde artırmıştır. Yüz yüze bir iletişim süreci olan AAİ artık internetin ortaya çıması ile sanal mecrada kendini gösteren bir iletişim haline gelmiş ve elektronik ağızdan ağıza iletişim (e-AAİ) kavramı ortaya çıkmıştır (Güzel, 2014:195). E - AAİ 
kavramı "İnternet üzerinden çok sayıda kişiye ve kurumlara sunulan bir ürün veya işletme hakkında potansiyel, gerçek veya eski müşteriler tarafından yapılan herhangi bir olumlu veya olumsuz ifade" olarak tanımlanmaktadır (Hennig-Thurau vd., 2004:39). E- AAİ, AAİ ile karşılaştıııldığında, e-AAİ'nin pazarlamacı tarafından oluşturulan bilgi kaynaklarından daha fazla güvenilirliğe, empatiye, alaka düzeyine sahip ve daha etkin olabileceği düşünülmektedir (Özaslan ve Meydan Uygur, 2014). Bu bağlamda artık yeni bir pazarlama kanalı olan internet, çevrimiçi alışveriş yapan tüketiciler için önemli bir bilgi kaynağı haline gelmiştir. Çevrimiçi alışveriş yapan tüketiciler, geleneksel perakende mağazalarında mümkün olduğu gibi ürünlere dokunamaz veya koklayamazlar, bu nedenle satın alma kararları, web sitesinde sunulan ürün bilgilerine dayanmaktadır. İşletmeler, tüketicilere ürün değerlendirmelerini çevrimiçi platformda paylaşma fırsatı vererek bu sınırlamanın üstesinden gelmeye çalışmaktadırlar. Tüketici tarafından yaratılan bu bilgi, satın alma kararlarında yardımcıdır, çünkü ürünlerin dolaylı deneyimlerini sağlamaktadır. İşletmeler hakkında bilgi edinme bağlamında günümüzde internet tabanlı e- AAİ, ürünü satın alan ve kullanan tüketiciler açısından sunulan yeni bilgiler, tüketiciler için önemli bir bilgi kaynağı haline gelmiştir (Lin vd., 2013:30-31). Son yıllarda internet kullanımının hızlı bir şekilde artmasıyla tüketiciler, deneyimledikleri ürünlerin olumlu ve olumsuz yönlerini internet ortamında yayınlayarak, tüketicilere deneyimlerini aktarmaktadırlar. Yapılan çalışmalar e-AAİ'nin tüketiciler üzerinde büyük ölçüde etkili olduğu sonucuna ulaşmıştır (Kitapcı vd., 2012:268).

İnternette ağızdan ağıza iletişimi kavramsal olarak ele alıp, pazarlama kapsamında ağızdan ağıza iletişimin hem geleneksel olarak hem de internette yapılan boyutu modelleri ortaya konmuştur (Akar, 2009). Çetin ve İstanbullu Dinçer (2014), e-AAİ'nin güvenilir bir ürün bilgisi kaynağ1 olarak etkisinin her geçen gün arttığını belirterek, konaklama işletmelerinin müşterilerine daha iyi hizmet vermelerine ve yeni müşterilere ulaşma olasılıklarını geliştirmelerine yardımcı olacağını savunmuşlardır.

Bu bağlamda e-AAİ konusuyla ilgili yapılan çalışmalara bakıldığında son yıllarda e-AAİ konusunun kavramsal boyutu, güvenilirliği, müşterilerin satın almasına etkisi, işletmeler açısından daha iyi hizmet verebilmek için gerekliliği ve yeni müşterilere ulaşmada sağladığı avantajları gibi konuların araştırıldığı görülmektedir. Yang ve arkadaşları 2018 yılında yapmış oldukları bir çalışmada, e-AAİ ile otel performansı arasındaki ilişkiyi incelemiş ve performans ölçümü, fiyat değişkeninin kontrolü ve işlev formu gibi bazı önemli konularda araştırmacılar ve otel işletmeleri için çıkarımlar sağlamıştır. Pourabedin ve Migin (2015), turizm endüstrisi özellikle otel işletmelerinin e-AAİ'den önemli ölçüde etkilendiğini belirterek olumlu e-AAI'nin faydalarını ve kolaylığını araştırmışlardır. Yapılan olumlu yorumların diğer seyahat edecekler için motive edici etkisini vurgulayarak pazarlama çalışanlarının çevrimiçi pazarlamada pratik çıarımları desteklemeleri gerektiğini belirtmişlerdir. Torlak ve arkadaşları (2014), e-AAÍnin marka imajı ve satın alma davranışı üzerindeki etkisini araştırmış ve her ikisinde de eAAİ arasında anlamlı pozitif bir ilişki olduğunu tespit etmişlerdir. Torres ve Sing (2016) e-AAİ'nin otel işletmelerine etkisini araştırmış ve bir çevrimiçi seyahat sitesinde yapılan yorumların otelin derecelendirilmesi ve incelenme sayısında e-AAİ'nin tam bir etkisinin olduğunu belirtmişlerdir.

İnternetin insanların görüşlerinin diğer tüketiciler için daha kolay ve hızlı bir şekilde erişilebilir olmasını sağlamasından dolayı e- AAİ, satın alma kararı veren tüketiciler için önemli bir kaynak olarak kabul edilmektedir. (Chevalier ve Mayzlin, 2006). Turistik ürün tüketicileri, turizm ürününün somut olmaması ve satın almadan önce deneyimleme imkanı olmamasından dolayı birçok kaynaktan yararlanma ihtiyacı duymaktadır (Tayfun vd., 2013:27). Çalışmaların sonuçlarına göre; turistlerin \%80'i tatil kararı alırken ve rezervasyon yaptırırken sanal ortamdaki tavsiyelerden faydalanmaktadır (Kutluk ve Avcıkurt, 2014:616). Buradan hareketle e-AAİ'in otel 
işletmelerinde yaratmış olduğu kurumsal imajın irdelenmesi çalışmanın amacını oluşturmaktadır.

\section{ARAŞTIRMANIN YÖNTEMI}

\section{Verilerin Toplanması}

Çalışmada Antalya' da faaliyet gösteren 5 yıldızlı otel işletmelerinin e-AAİ aracılığıyla imajlarının irdelenmesi amaçlanmıştır. Bu bağlamda bir seyahat sitesinde Antalya'da faaliyet gösteren 5 yıldızlı otel işletmeleri hakkında yapılan çevrimiçi yorumlar incelenmiştir.

Tablo 1. Yorumları İndirilen Oteller ve Yorum Adetleri

\begin{tabular}{|c|c|c|}
\hline Otel sayısı & Otel Adı & Yorum Adedi \\
\hline 1 & Antalya Adonis Hotel & 102 \\
\hline 2 & Akra Hotel & 728 \\
\hline 3 & Aska Lara Resort and Spa & 1190 \\
\hline 4 & Asteria Kremlin Palace & 1257 \\
\hline 5 & Baia Lara & 656 \\
\hline 6 & Club Hotel Sera & 359 \\
\hline 7 & Concorde De Luxe Resort & 862 \\
\hline 8 & Crown Plaza Antalya & 1343 \\
\hline 9 & Delphin BE Grand Resort & 138 \\
\hline 10 & Dream Hotel & 20 \\
\hline 11 & Fame Residence Lara and SPA & 180 \\
\hline 12 & Harrington Park Resort & 118 \\
\hline 13 & Hotel Su & 474 \\
\hline 14 & IC Hotel & 53 \\
\hline 15 & Liberty Hotel & 625 \\
\hline 16 & Limak Lara De Lexu Hotel and Resort & 1001 \\
\hline 17 & The Marmara Antalya & 453 \\
\hline 18 & Melas Lara Hotel & 166 \\
\hline 19 & Miracle Resort Hotel & 329 \\
\hline 20 & Oz Hotel Antalya Resort Spa & 59 \\
\hline 21 & Özkaymak Falez Hotel & 105 \\
\hline 22 & Porto Bello Hotel & 927 \\
\hline 23 & Ramada Plaza & 824 \\
\hline 24 & Ramada Hotel & 1328 \\
\hline 25 & Rixos Downtown Antalya & 699 \\
\hline 26 & Royal Holiday Palace & 317 \\
\hline 27 & Royal Seginus & 202 \\
\hline 28 & Sealife Family Hotel & 690 \\
\hline 29 & Sherwood Hotel & 19 \\
\hline 30 & Swandar Hotel & 643 \\
\hline 31 & Titanic Beach Lara & 1146 \\
\hline 32 & Titanic Mardan Palace & 161 \\
\hline 33 & Venezia Hotel & 480 \\
\hline 34 & Villa Tullipan & 68 \\
\hline \multirow[t]{2}{*}{35} & Wind of Lara Hotel & 339 \\
\hline & Toplam & 18061 \\
\hline
\end{tabular}


Seyahat sitesinden Antalya destinasyonu ve oteller kısmından filtreleme yapıldığında toplam 35 adet 5 yıldızlı otel olduğu görülmektedir. Örneklem olarak Antalya'nın seçilmesinin nedeni 2018 verilerine göre yaklaşık 14 milyon turist ağırlaması ve turizm anlamında popüler bir destinasyon olmasıdır. 5 yıldızlı oteller üzerine odaklanılmasının nedeni ise daha kurumsal bir yapılarının olması ve lüks hizmet sunmalarıdır. Seyahat sitesindeki Antalya 5 yıldızlı otellerine ait toplam 18061 çevrimiçi yorum analiz edilmiştir. Çevrimiçi yorumlar Ekim 2019 tarihinde elde edilmiştir. Yorumları indirilen otellerin isimleri ve her otele ait yorum adetleri Tablo 1'de belirtilmiştir.

Otellere ilişkin yorumlar Web madenciliği yapmak için kullanılan özel bir programla indirilmiş ve veriler Excel programına aktarılarak, metin madenciliği uygulamasında kullanılabilecek şekilde bir veri setine dönüştürülmüştür. Tablo 2' de Otel yorumlarına ait üç satırlık veri seti örneği görülmektedir.

Tablo 2. Otel Yorumları Örnek Veri Seti

\begin{tabular}{|c|c|c|}
\hline ID & Otel Adı & Yorum \\
\hline 1 & $\begin{array}{l}\text { Antalya Adonis } \\
\text { Hotel }\end{array}$ & $\begin{array}{l}\text { “Çıkana kadar sorun yoktu .... çıacă̆ımız gün kolumuza } \\
\text { kırmızı bileklik taktılar bunun manası imkanlardan kısıtlı } \\
\text { yararlanıyorsunuz demekmiş öyle ortalarda gezin bir an } \\
\text { önce otelimizi terk edin bilekliği de olabilir .... zira } \\
\text { gözlemeye bile sabah para almaya kalktılar neyse bir..." }\end{array}$ \\
\hline 2 & Akra Hotel & $\begin{array}{l}\text { “Öncelikli olarak Otel Konumu olarak mükemmel, Otel } \\
\text { odaları kahvaltısı yemekleri lezzetli. Manzarasına } \\
\text { denilecek tek söz yok. En Üst katta bulunan restaurantta } \\
\text { Gün batımı seyretmek ve şarap keyfi paha biçilemez. Giriş̧ } \\
\text { kattaki Pablito bistro gayet başarılı Pizzaları mükemmel.” }\end{array}$ \\
\hline 3 & $\begin{array}{l}\text { Aska Lara Resort } \\
\text { and Spa }\end{array}$ & $\begin{array}{l}\text { "otel yeni odalar manzara güzel beğendik hizmet iyiydi } \\
\text { personel iyiydi tam bebek ve çocuk dostu her şey mevcut } \\
\text { tavsiye ederiz mini kulübü çok beğendik çalışanları da } \\
\text { ilgiliydi aqua parklar eğlenceli ve güzeldi tatlılar } \\
\text { yemekler güzeldi" }\end{array}$ \\
\hline
\end{tabular}

\section{Veri Ön İşleme}

Verilerin indirilmesi aşamasından sonra metin ve veri madenciliği aşamasına geçilmiştir. Bu aşama için RapidMiner programı kullanılmıştır. RapidMiner kullanımı kolay, açık kaynak kodlu ve birçok akademik çalışmada kullanılan bir veri madenciliği yazılımı olması sebebiyle tercih edilmiştir. Yale Üniversitesi'nde bilim adamları tarafından Java dili kullanılarak geliştirilen RapidMiner programı büyük ölçekli veriden anlamlı bilgiler elde etmek için kullanılır (Albayrak, 2015:756). Veri madenciliği, metin madenciliği, tahmine dayalı analitik ve iş analitiği için entegre bir ortam sağlayan yazılım; veri ön işleme, sonuç görselleştirme, doğrulama ve optimizasyon dahil olmak üzere veri madenciliği süreçlerinin tüm adımlarını desteklemektedir (Arunadevi vd., 2018:15983).

Verilerin elde edilmesi kapsamında oluşturulan excel dosyası RapidMiner veri madenciliği programına eklenmiştir. Aktarma sırasında her sütun bir öznitelik olarak seçilmiştir. Daha sonra yorumlarda geçen kelimelerin tek tek ayrılması için model oluşturulmuştur. Buradaki amaç yorumlarda geçen kelimeleri birer öznitelik olarak belirleyerek kelime frekansları elde etmek ve ayrıca birliktelik analizine uygun duruma getirmektir. 
Veri ön işleme aşamasında oluşturulan modelin desing görünümü Şekil 1'de görülmektedir.

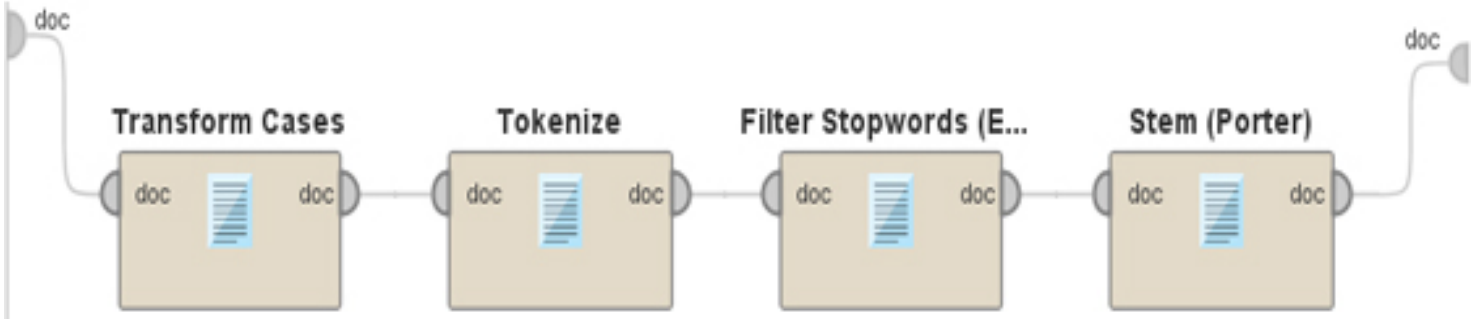

Şekil 1. Veri Ön İşleme desing görünümü

Şekil 1'de görüldüğü üzere kelime frekansları elde etmek için sırasıyla "Dönüştürücü, Dizgeci, Anahtar kelimeler filtreleme ve kök işlemleri" operatörleri kullanılmıştır.

Tablo 3. Elde Edilen Yorumlara İlişkin Kelime Frekansları

\begin{tabular}{|c|c|}
\hline Kelimeler & Kelime Frekansı \\
\hline otel & 21232.0 \\
\hline yemek & 9266.0 \\
\hline personel & 6897.0 \\
\hline oda & 6499.0 \\
\hline tatil & 4549.0 \\
\hline havuz & 4048.0 \\
\hline hizmet & 2665.0 \\
\hline animasyon & 2124.0 \\
\hline temizlik & 1981.0 \\
\hline ekip & 1910.0 \\
\hline zaman & 1756.0 \\
\hline servis & 1730.0 \\
\hline çalışan & 1558.0 \\
\hline plaj & 1476.0 \\
\hline çocuk & 1431.0 \\
\hline tekrar & 1406.0 \\
\hline yer & 1313.0 \\
\hline arkadaş & 1257.0 \\
\hline aile & 1205.0 \\
\hline restoran & 1174.0 \\
\hline misafir & 1024.0 \\
\hline merkez & 1022.0 \\
\hline tesis & 956.0 \\
\hline kahvaltı & 846.0 \\
\hline sahil & 790.0 \\
\hline içecek & 742.0 \\
\hline bar & 706.0 \\
\hline çeşitli & 678.0 \\
\hline manzarası & 673.0 \\
\hline her şey & 619.0 \\
\hline yiyecek & 599.0 \\
\hline fiyat & 596.0 \\
\hline restaurant & 596.0 \\
\hline aktivite & 554.0 \\
\hline
\end{tabular}


“Dönüştürücü" operatörünün parametresi olarak "küçük harf" tercih edilerek yorumlarda geçen kelimelerin tamamı küçük harfe dönüştürülmüştür. Böylelikle kelime gruplarındaki büyükküçük harf sorunu ortadan kaldırılmıştır. Daha sonra yorum içerisindeki kelimeler "dizgeci" operatörü ile tek tek parçalara ayrılmıştır. "anahtar kelimeleri filtreleme" operatörü ile ise parçalanan kelimelerde bulunan bağlaç, zamir, edat gibi sözcük yapıları filtrelenmiştir. "kök işlemleri" operatörü ile de aynı kökten gelen kelimeler tek bir kelime kökünde birleştirilmiştir. Şekil 1'de gösterilen model çalıştırıldığında yorumlarda geçen kelimelere ait kelime frekansları elde edilmiştir. Tablo 3'te elde edilen kelime frekanslarının büyükten küçüğe doğru sıralaması görülmektedir.

Tablo 3 incelendiğinde en fazla otel (21 232 yorum), yemek (9 266 yorum), personel (6 897 yorum), oda (6 499 yorum) ve tatil (4 549 yorum) kelimelerinin yorumlarda geçtiği görülmektedir. En az bahsedilen kelimeler ise, aktivite (554 yorum), restoran (596 yorum), fiyat (596 yorum) ve yiyecek (599 yorum) kelimeleridir.

Tablo 4. Yorumlarda Geçen Sıfatlara Yönelik Kelime Frekansları

\begin{tabular}{|l|c|}
\hline Kelimeler & Kelime Frekansı \\
\hline güzel & 8282.0 \\
\hline harika & 5231.0 \\
\hline mükemmel & 2877.0 \\
\hline ilgili & 1598.0 \\
\hline lezzetli & 1462.0 \\
\hline arkadaşça & 1257.0 \\
\hline muhteşem & 1149.0 \\
\hline rahat & 1043.0 \\
\hline güler yüzlü & 995.0 \\
\hline kaliteli & 868.0 \\
\hline süper & 839.0 \\
\hline yardımsever & 836.0 \\
\hline yardımcı & 753.0 \\
\hline kötü & 740.0 \\
\hline sıcak & 671.0 \\
\hline eski & 637.0 \\
\hline ferah & 566.0 \\
\hline başarılı & 556.0 \\
\hline küçük & 553.0 \\
\hline eğlenceli & 528.0 \\
\hline
\end{tabular}

Tablo 4 incelendiğinde otellere yönelik yapılan yorumlarda hiç olumsuz bir sıfatın kullanılmadığ görülmektedir. En fazla "güzel" kelimesinin geçtiği (8282 yorum), en az ise "eğlenceli" (528 yorum) kelimesinin kullanıldığı tespit edilmiştir. Genel olarak olumlu yorumlara bakıldığında otellerle ilgili "güzel, harika, mükemmel, ilgili, lezzetli, arkadaşça, muhteşem" kelimeleri kullanarak memnuniyetlerini belirttikleri söylenebilir. 


\section{Birliktelik Analizi}

Birliktelik analizi, veri setinde bulunan nesneler arasındaki ilişkileri saptayan ve bir nesnenin diğer nesne ile bağlantısını açıklayan bir analiz türüdür. Kelime frekansı analizi yapıldığında ortaya çıkan kelime kökleri birliktelik analizine tabi tutulmuş ve yorumlarda birlikte geçen kelimelere ait birliktelik kuralları ortaya çıkarılmıştır. Böylece Antalya 5 yıldızlı otellerine ilişkin yorumlarda geçen kelimelerin hangi sıklıkla birlikte geçtiği güven parametreleri ile belirlenmiş ve ziyaretçilerin otel imajı ile ilgili algıları tespit edilmiştir.

Birliktelik analizi için uygulamada kullanılan model Şekil 2'de görülmektedir.

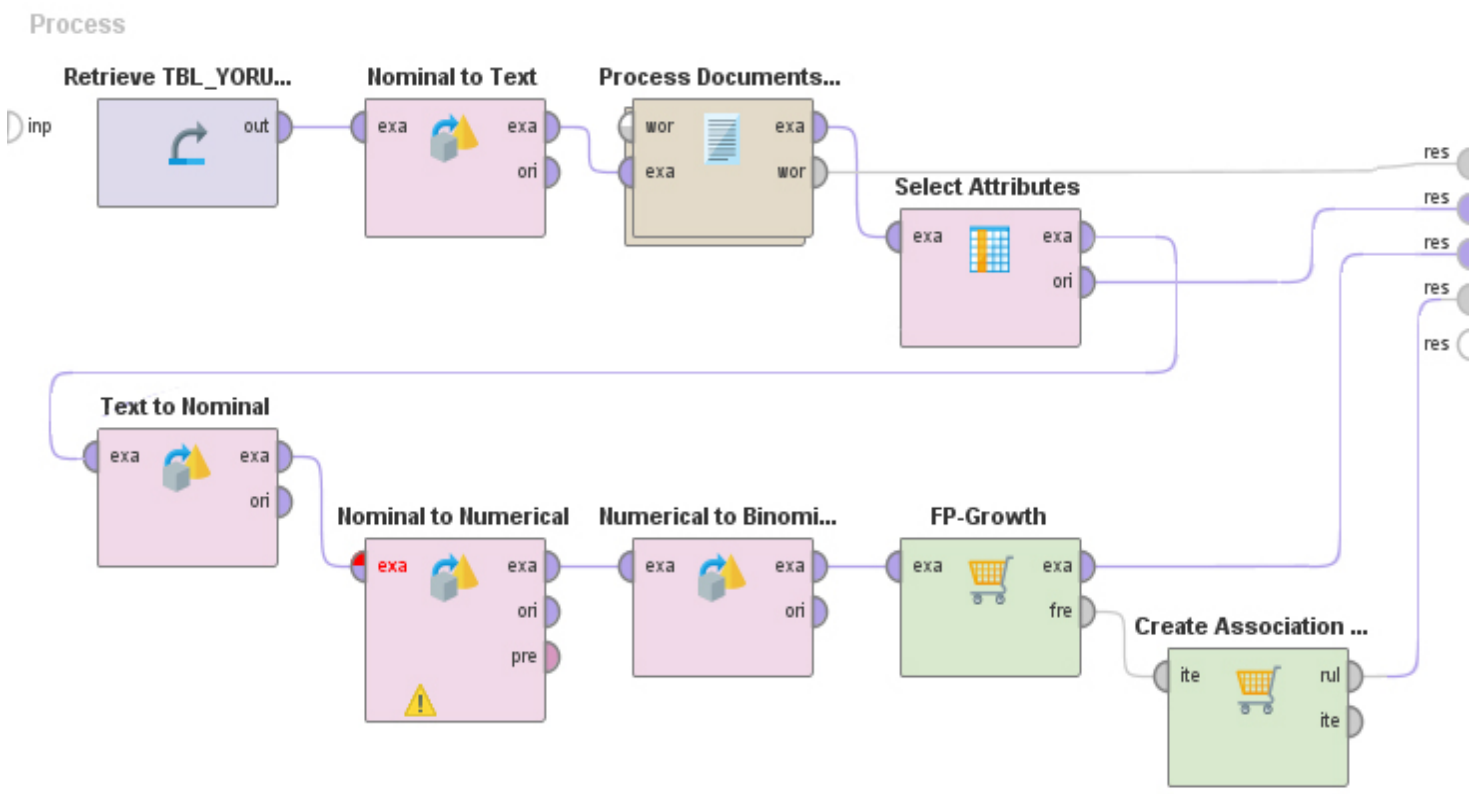

Şekil 2. Araştırma Modeli

Şekil 2'ye göre Process Documents klasörünün içerisinde elde edilen kelime frekansları Select Attributes ile birer özelliğe döndürülmüştür. Kelimeler arasındaki birliktelik kurallarının çıkarımı için bir yorumda o kelimenin geçip geçmediğinin bilinmesi gereklidir. Bunun için ise öncelikle kelime matrisi oluşturulmuştur. Kelime matrisinin oluşturulabilmesi için oluşturulan Attributes'ler 'Text to Nominal, Nominal to Numerical, Numerical to Binominal' aşamalarından geçilerek kelime matrisi elde edilmiştir. Tablo 4'te örnek kelime matrisi görülmektedir.

Tablo 5 Örnek Kelime Matrisi

\begin{tabular}{|l|l|l|l|l|l|l|l|l|l|}
\hline $\mathbf{N o}$ & Animasyon & Büyük & Çalışan & Restoran & Oda & Havuz & Temizlik & Lezzetli & Muhteşem \\
\hline $\mathbf{1}$ & Yanlış & Doğru & Yanlış & Doğru & Yanlış & Doğru & Doğru & Yanlış & Doğru \\
\hline $\mathbf{2}$ & Doğru & Yanlış & Doğru & Yanlış & Doğru & Yanlış & Yanlış & Doğru & Yanlış \\
\hline $\mathbf{3}$ & Doğru & Doğru & Yanlış & Doğru & Doğru & Yanlış & Doğru & Doğru & Doğru \\
\hline $\mathbf{4}$ & Doğru & Doğru & Doğru & Doğru & Yanlış & Doğru & Yanlış & Yanlış & Yanlış \\
\hline $\mathbf{5}$ & Yanlış & Doğru & Doğru & Yanlış & Doğru & Doğru & Doğru & Doğru & Doğru \\
\hline
\end{tabular}

Tablo 5'te görüldüğü üzere bir yorumda ilgili kelime geçiyorsa 'doğru', geçmiyorsa 'yanlış' değerini almıştır. Daha sonra elde edilen kelime matrisi birliktelik analizine tabi tutularak 
birliktelik kuralları elde edilmiştir. Kural oluşumunda tercih edilen algoritma ise Şekil 2'de görüldüğü üzere Fp-Growth algoritmasıdır. Fp-Growth algoritması bir veri setinde en sık kullanılan öğeleri belirlemek için kullanılan bir algoritmadır. Böl-yönet stratejisini kullanan bu algoritma veri setindeki öğeleri tarar ve destek değerlerini hesaplayarak veri ağacı ile kurallar oluşturur (Ikhwan vd., 2018:1663). Birliktelik analizi ile kurallar oluşturmada Confidence ve Support ölçütlerinden yararlanılır. Kurulan modele göre Confidence değeri 0.68 , support değeri ise 0.1 olarak belirlenmiştir. Bu kapsamda analiz sonucunda 31 adet kural elde edilmiştir. Tablo 6 'te elde edilen bu kurallar listelenmektedir.

Tablo 6. Otellere İlişkin Birliktelik Kuralları Tablosu

\begin{tabular}{|l|c|c|}
\hline Kelimeler & Sonuç & Güvenilirlik Değeri \\
\hline güzel, büyük & otel & 0.81 \\
\hline harika & otel & 0.80 \\
\hline oda, büyük & otel & 0.77 \\
\hline personel, güzel, harika & otel & 0.76 \\
\hline oda, geniş & otel & 0.76 \\
\hline ferah & otel & 0.75 \\
\hline manzara & otel & 0.75 \\
\hline kaliteli & otel & 0.75 \\
\hline harika, havuz & otel & 0.74 \\
\hline muhteşem & otel & 0.74 \\
\hline oda, rahat & otel & 0.74 \\
\hline harika, zaman & otel & 0.74 \\
\hline güzel, plaj & otel & 0.74 \\
\hline personel, yardımsever & otel & 0.74 \\
\hline havuz, büyük & otel & 0.74 \\
\hline yemek, harika, havuz & otel & 0.73 \\
\hline personel, harika & otel & 0.73 \\
\hline yemek, personel, harika & otel & 0.73 \\
\hline harika, mükemmel & otel & 0.72 \\
\hline güzel, ilgili & otel & 0.72 \\
\hline rahat & otel & 0.72 \\
\hline süper & otel & 0.72 \\
\hline eğlence & otel & 0.71 \\
\hline yemek, güzel, harika & otel & 0.71 \\
\hline personel, güler yüzlü & otel & 0.71 \\
\hline personel, ilgili & otel & 0.71 \\
\hline kalma, memnun & otel & 0.70 \\
\hline personel, oda, harika & otel & 0.70 \\
\hline yemek, lezzetli & otel & 0.70 \\
\hline eder, tavsiye & otel & 0.68 \\
\hline güzel, ekip & otel & 0.68 \\
\hline & & \\
\hline
\end{tabular}

Tablo 6 incelendiğinde "otel" kelimesinin "güzel" ve "büyük" kelimeleri ile birlikte geçme sıklı̆̆1 confidence değerine göre 0,81 'dir. En düşük confidence değeri "güzel" ve "ekip" kelimelerinin birlikte geçme sıklığı değeridir $(0,68)$. 
Tablo 7. Otel Personellerine İlişkin Birliktelik Kuralları Tablosu

\begin{tabular}{|l|c|c|}
\hline Kelimeler & Sonuç & Güvenilirlik Değeri \\
\hline otel, yardımsever & personel & 0.81 \\
\hline yardımsever & personel & 0.78 \\
\hline
\end{tabular}

Tablo 7 incelendiğinde "personel" kelimesinin "otel" ve "yardımsever" kelimeleri ile birlikte geçme sıklığı confidence değerine göre 0,81 'dir. Birlikte geçme sıklığ confidence değerleri incelendiğinde, personelle ilgili yorumlarda otel personelinin "yardımsever" olduğu sonucuna ulaşılmıştır.

Tablo 8. Otellerde Sunulan Yemeklere İlişkin Birliktelik Kuralları Tablosu

\begin{tabular}{|l|c|c|}
\hline Kelimeler & Sonuç & Güvenilirlik Değeri \\
\hline personel, lezzetli & yemek & 0.89 \\
\hline oda, lezzetli & yemek & 0.89 \\
\hline lezzetli & yemek & 0.88 \\
\hline otel, lezzetli & yemek & 0.88 \\
\hline güzel, lezzetli & yemek & 0.88 \\
\hline çeşitli & yemek & 0.79 \\
\hline
\end{tabular}

Tablo 8 incelendiğinde "yemek" kelimesinin "personel" ve "lezzetli" kelimeleri ile birlikte geçme sıklığı confidence değerine göre $0,89^{\prime}$ dur. En düşük confidence değeri "yemek" ve "çeşitli" kelimelerinin birlikte geçme sıklığı değeridir $(0,79)$. Birlikte geçme sıklığı confidence değerleri incelendiğinde, yemeklerle ilgili yorumlarda yemeklerin "lezzetli ve güzel" olduğu tespit edilmiştir.

Tablo 9. Otellere İlişkin Birliktelik Kuralları Tablosu

\begin{tabular}{|l|c|c|}
\hline \multicolumn{1}{|c|}{ Kelime } & Sonuç & Güvenilirlik Değeri \\
\hline ferah & oda & 0.72 \\
\hline geniş & oda & 0.69 \\
\hline otel, geniş & oda & 0.69 \\
\hline
\end{tabular}

Tablo 9 incelendiğinde "oda" kelimesinin "geniş" ve "otel" kelimeleri ile birlikte geçme sıklığ confidence değerine göre 0, 72'dir. En düşük confidence değeri "otel ve "geniş" kelimelerinin birlikte geçme sıklığı değeridir $(0,69)$. Birlikte geçme sıklığı confidence değerleri incelendiğinde, odalarla ilgili yorumlarda otel odalarının "geniş ve ferah" olduğu elde edilen yorumlar doğrultusunda ortaya çıkmıştır.

Yorumlar genel olarak incelendiğinde turistlerin otel işletmeleriyle ilgili olumlu bir algilarının olduğu (güzel, harika, mükemmel, ilgili, lezzetli, arkadaşça, muhteşem) ve otellerin olumlu bir imaja sahip olduğu söylenebilir. Bu sonuç yapılan çalışmaların sonuçlarıla paralellik göstermektedir (Ateşoğlu ve Bayraktar, 2011; Kitapçı vd., 2012; Lin vd., 2013; Kutluk ve Avcıkurt, 2014; Aydın 2016). 


\section{SONUÇ ve ÖNERILER}

Yapılan çalışmalar incelendiğinde günümüzde ağızdan ağıza iletişimin; turistlerin satın alma davranışlarına, tatminine, sadakatine, destinasyon seçimine, otel işletmesine karar vermesine, otellerdeki oda satışına, destinasyon ve işletme imajına önemli etkisi olduğu görülmektedir. İşletme imajının belirlenmesinde fiyat, fiziksel yapı, personel, ürün, hizmet gibi faktörler yer almaktadır. Çalışmanın amacını oluşturan Antalya'da faaliyet gösteren 5 yıldızlı otel işletmelerinin e-AAİ aracılığıyla imajlarının belirlenmesi amacıyla incelen bir seyahat sitesinde yer alan 18061 yorum da bu kapsamda incelenmeye çalışılmıştır. Yapılan analizler sonucunda turistlerin en fazla otelin fiziki yapısı (21 232 yorum) hakkında yorum yaptığı görülmektedir. Fiziki yapının ardından 9266 yorum ile yemek, 6897 yorum ile personel, 6499 yorum ile oda ve hizmet konuları hakkında yorum yapılmıştır. Fiyat ise en az yorum yapılan bir boyut olduğu tespit edilmiştir. Otel işletmelerinden beklenen hizmet soyut olduğundan ve kişiye göre algılanan hizmet kalitesi değişeceğinden en fazla yorum bu konularda olmuşken, turistlerin 5 yıldızlı otel için ödedikleri fiyatın önceden belirli olması bu konuda yapılan yorumun az olmasının nedeni olarak düşünülebilir.

İrdelenen yorumlara bakıldığında örneklem kapsamındaki oteller hakkında olumsuz hiçbir sıfatın kullanılmadığı dikkat çekmektedir. Oteller ile ilgili "güzel (8 282 yorumda), harika (5 231 yorumda), mükemmel (2 877 yorumda)" gibi olumlu sıfatların kullanılması otelde konaklayan turistlerin genel itibariyle tatillerini geçirdikleri otelden memnun olduklarının göstergesidir. Yapılan birliktelik analizi sonucunda otel kelimesi ile birlikte geçme sıklığının 0,75 ten büyük olan güzel, büyük, harika, geniş, ferah ve kaliteli sıfatlarının olduğu görülmektedir. Bu bağlamda yapılan yorumlardan turistlerin genel olarak memnun olduğu düşünülmektedir.

Turistlerin otel odaları hakkında en fazla yapmış olduğu ferah ve geniş yorumu örneklem kapsamındaki otellerin bu konuda bir standardı yakaladığını göstermektedir. Ayrıca diğer iki boyut hakkında yapılan yorumlar personelin güler yüzlü ve yardımsever olduğu ve yemeklerin lezzetli olduğunu göstermektedir. Genel olarak yapılan yorumlar ışı̆̆ında örneklem kapsamındaki otel işletmeleri hakkında "güzel, harika, mükemmel, ilgili, lezzetli, arkadaşça, muhteşem" ifadeleri kullanılarak turistlerin memnuniyetlerini belirttikleri görülmekte ve otel işletmelerinin olumlu imaja sahip olduğu sonucuna varılabilmektedir.

İşletmeler, çevrimiçi yorumların müşteriler üzerinde önemli etkiye sahip olduğunu göz ardı etmemeli ve günümüz rekabet piyasasında hayatta kalabilmek için e-AAI'́e önem vermelidir. Çalışmada sadece bir seyahat sitesindeki yorumların incelenmesi çalışmanın kısıtını oluşturmaktadır. Bundan sonra yapılacak olan çalışmalarda araştırmacılara, kapsamı genişletmek amacıyla birden fazla sitenin incelenmesi tavsiye edilmektedir. Ayrıca sadece işletme imajı değil, destinasyon imajının da belirlenmesi çalışması yapılabilir ve farklı dillerde yapılan yorumlar kıyaslanabilir.

\section{KAYNAKÇA}

Akar, E. (2009). Pazarlama bağlamında geleneksel ve internette ağızdan ağıza iletişim: kuramsal bir çerçeve. Erciyes Üniversitesi İktisadi ve İdari Bilimler Fakültesi Dergisi, 32, 113-134.

Albayrak, M. (2015). Bilimsel araştırmalarda veri madenciliği kullanımı. International Journal of Social Sciences and Education Research, 3(3), 751-760.

Arunadevi, J., Ramya, S. and Raja, M. R. (2018). A study of classification algorithms using Rapidminer. International Journal of Pure and Applied Mathematics, 119(12), 15977-15988. 
Ateşoğlu, İ. ve Bayraktar, S. (2011). Ağızdan Ağıza Pazarlamanın Turistlerin Destinasyon Seçimindeki Etkisi, ZKÜ Sosyal Bilimler Dergisi, 7(14), 95 - 108.

Aydın, B. (2016). Sosyal Medyada Restoran İmajı: Tripadvisor Örneği, Disiplinlerarası Akademik Turizm Dergisi, 1, (1), 13-30.

Brown, T. J., Barry T.E., Dacin P. A. and Gunst R. F. (2005). Spreading the Word: Investigating Antecedents of Consumers' Positive Word-of-Mouth Intentions and Behaviors in a Retailing Context, Journal of the Academy of Marketing Science. 33(2), 123-138.

Buttle, F. A. (1998). Word of mouth: Understanding and managing referral behavior. Journal of Strategic Marketing, 6(3), 241-254.

Chevalier, J. and Mayzlin, D. (2006). The effect of word of mouth on sales: Online book reviews. Journal of Marketing Research, 43(3), 345-354.

Çetin, G. ve İstanbullu Dinçer, F., (2014). Electronic word of mouth among hotel guests: demographic and tripographic factors. Bilgi Ekonomisi ve Yönetimi Dergisi, 9(2), 35 - 41.

Güzel, F. Ö., (2014). Deneyimsel Kritik Değer Sürücülerinin Elektronik Ağızdan Ağıza İletişimle Seyahat 2.0 Bilgi Kanallarına Yansıması: Trıpadvısor.Com Üzerinde Bir İçerik Analizi, Uluslararası Yönetim İktisat ve İşletme Dergisi, 10(22), 193 - 210.

Ikhwan, A., Yetri, M., Syahra, Y., Halim, J., Siahaan, A. P. U., Aryza, S. and Yacob, Y. M. (2018). A Novelty of Data Mining for Promoting Education based on FP-Growth Algorithm. International Journal of Civil Engineering and Technology, 9(7), 1660-1669.

Keller, K. L. (1998). Strategy Brand Management: Building, Measuring, and Managing Brand Equity, 2nd edition. New Jersey: Prentice Hall.

Kitapçı, O., Taştan, S., Dörtyol, İ.T. ve Akdoğan, C., (2012). Ağızdan Ağıza Çevrimiçi İletişimin Otellerdeki Oda Satışlarına Etkisi Üzerine Bir Araştırma, Doğuş Üniversitesi Dergisi, 13(2), 266274

Kozak, N. (2014). Turizm Pazarlaması, 6. Baskı, Detay Yayıncılık, Ankara.

Kutluk, A. ve Avcıkurt, C. (2014). Ağızdan Ağıza Pazarlamanın Müşterilerin Satın Alma Karar Süreçlerine Etkisi ve Bir Uygulama: (İstanbul Seyahat Acenteleri Örneği), Uluslararası Sosyal Araştırmalar Dergisi, 7(29), $613-622$.

Lin, C., Wu, Y.S. and Chen, J. C. V. (2013). Electronic Word-of-Mouth: The Moderating Roles of Product Involvement and Brand Image, Proceedings of 2013 International Conference on Technology Innovation and Industrial Management, 29 - 31 May 2013, Phuket, Thailand.

Marangoz, M. ve Akyıldız, M. (2007). Algılanan Şirket İmajı ve Müşteri Tatmininin Müşteri Sadakatine Etkileri, Yönetim Bilimleri Dergisi 5(1), 194-218.

Özaslan, Y. ve Meydan Uygur, S. (2014). Negatif Ağızdan Ağıza İletişim (WOM) ve Elektronik Ağızdan Ağıza İletişim (E-WOM): Yiyecek-İçecek İşletmelerine Yönelik Bir Araştırma, Atatürk Üniversitesi İktisadi ve İdari Bilimler Dergisi, 28(3), 69 - 88.

Padgett, D. and Allen, D. (1997). Communicating experiences: A narrative approach to creating service brand image. Journal of Advertising, 26(4), 49-62.

Pourabedin, Z. and Migin, W. M. (2015). Hotel experience and positive electronic World of mouth (e-WOM). International Business Management, 9 (4), 596 - 600.

Şimşek, S. (1998). Yönetim ve Organizasyon, 4. Baskı, Konya. 
Tayfun, A., Yıldırım, M. ve Kaş, L. (2013). Turistlerin Turistik Ürün Tercihlerinde Ağızdan Ağıza İletişimin Rolü: Yerli Turistler Üzerine Bir Araştırma, Journal of Tourism and Gastronomy Studies, 1(2), 26-38.

Torlak, Ö., Özkara, B. Y., Tiltay, M. A., Cengiz, H. and Dülger, M. F. (2014). The Effect of Electronic Word of Mouth on Brand Image and Purchase Intention: An Application Concerning Cell Phone Brands for Youth Consumers in Turkey, Journal of Marketing Development and Competitiveness, 8(2), $61-68$.

Torres, E. N. and Sing, D. (2016). Towards a Model of Electronic Word-of-Mouth and Its Impact on the Hotel Industry, International Journal of Hospitality \& Tourism Administration, 17:4, 472-489.

Yang, Y., Park, S. and Hu, X. (2018). Electronic word of mouth and hotel performance: A metaanalysis. Tourism Management. 67, 248-260.

Zengin, B. ve Gürkan, Z. (2009). Konaklama Sektöründe Kurumsal İmajin Önemi ve Tüketici Tercihlerine Etkileri, Journal of Azerbaijan Studies, 12 (2), 132-157. 